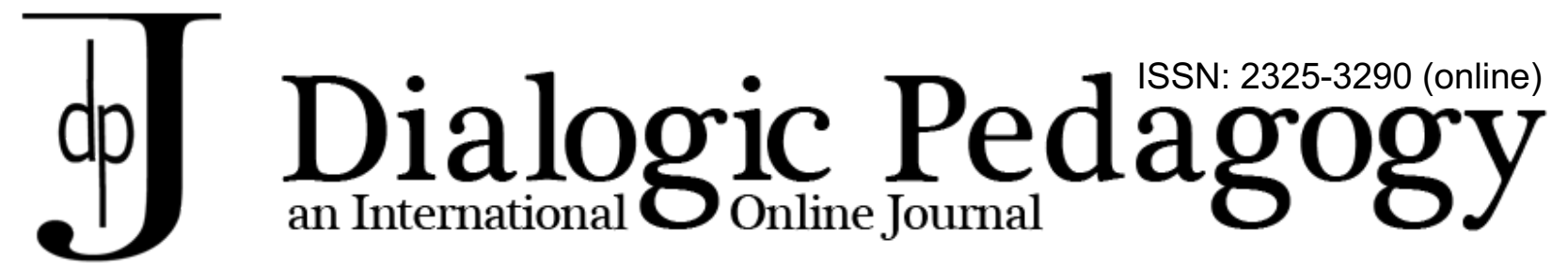

\title{
Sink or swim? Responsible situated agency constructed by socioeconomically underprivileged students of English in neoliberal Brazil
}

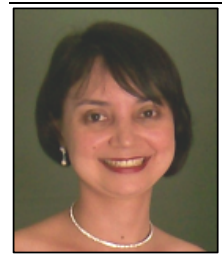

\author{
Carla Janaina Figueredo
}

Federal University of Goiás, Brazil

\begin{abstract}
This article discusses the results of a four-year investigation on the neoliberal challenges faced by socioeconomically underprivileged students in Brazil who were majoring in English teaching. It is a qualitative study that employs the concept of language as a sociocultural and dialogical practice as well as the concepts of responsibility and agency; it also examines the relationship between these students' experiences and neoliberalism as seen in language education. The data generated by questionnaires, students' narratives, and semi-structured interviews reveal that the participants' initiatives to engage themselves both in and outside academic interactional contexts acted as counter-centralizing forces. By exercising their responsible situated agency towards their English language appropriation process and teaching practice, they acted dialogically against neoliberal challenges understood here as hierarchical centripetal forces that constrain their access to different kinds of capital. The study outcomes suggest that decolonial and selfdecolonial practices should be heightened in the second language education program in question so that both undergraduates and faculty can confront traits of marginalization and self-marginalization resulted from the hegemony of neoimperial English. In doing so, more students can become part of "discursive actions" that foster their responsible situated agency towards a more egalitarian society.
\end{abstract}

\section{Keywords}

Second language education; neoliberalism; socioeconomically underprivileged students; agency; dialogical practices.

Carla Janaina Figueredo is a tenured Professor of the Second Language Education Program (English Area) and of the Graduate Program in Linguistics at Federal University of Goiás (Universidade Federal de Goiás - UFG), Goiânia, Brazil. She has a PhD in Applied Linguistics from Federal University of Goiás and a post-doctoral degree in Second Language Education from University of British Columbia (UBC), Vancouver, Canada. She is one of the organizers of "Language teaching in contemporaneity: practices of identity construction" (Ensino de Línguas na Contemporaneidade: práticas de construção de identidades Editora Pontes).

2ds 


\section{Sink or swim? Responsible situated agency constructed by socioeconomically underprivileged students of English in neoliberal Brazil}

Carla Janaina Figueredo

\section{Introduction}

The first time I heard the expression 'Sink or swim?' was during a workshop on English Phonology, held by the one-day BrazTesol Seminar, in 1994. My participation in that event was part of my academic activities as an undergraduate doing the first of a five-year program, which would enable me to major both in the English language and its teaching. Although the workshop teacher was emphasizing how easily second language learners of English could mispronounce the sound $/ \theta /$ by replacing it either for $/ \mathrm{s} /$ or $/ \mathrm{t} /$, my attention had been drawn to the meaning of that question and how well it translated my anxiety over the uncertainties that haunted my choice of getting a degree in a language I could barely speak. Throughout that first year, I struggled with that question in mind by always trying to find an answer for the following dilemma: should I surrender to the social and academic challenges imposed by this context and definitely 'sink' in my attempts to overcome my persistent linguistic and communicative constraints, or should I strive to learn how to swim against these currents? Even though my grades in the English language-related subjects were not far above the required average by the end of my first year in college, I decided to face the second year. This brief account is actually part of the background that underlies the case study I present in this article.

My interest to carry out this research was firstly born out of my own experience as a socioeconomically underprivileged undergraduate who decided to 'swim' against the neoliberal currents which flooded both my English learning process and my early teaching practice in the nineties. Twenty years later, now working as a professor of applied linguistics at the same Brazilian university from which I got my degrees in language education, this research also arises from the necessity of looking into the very same academic context and problematizing how Brazilian undergraduates majoring in English tend to respond to second language learning/teaching challenges deeply guided by neoliberal forces. This study also points to the urgency for more proactive research in the field of applied linguistics, that is, work which "involves paying attention to the local exigencies of learning and teaching, identifying researchable questions, producing original knowledge, and subjecting it to further verification" (Kumaravadivelu, 2016, p.17). Given that, socioeconomically underprivileged undergraduates majoring in English are the focal point of my discussions since they should represent the ultimate goal when it comes to lessening social inequalities in the promotion of a more egalitarian society. By problematizing their responses to this neoliberal-driven academic context, I also expect to better understand their 'agency' in relation to their English appropriation process and first teaching experiences. These research findings can potentially guide the participants to widen their dialogical practices by means of English as their second language. Moreover, it is also expected that the study outcomes enlighten the current faculty's agency to different language education perspectives by which the whole student body, regardless of their socioeconomic positions, can be better prepared to exercise their foreign or second language teaching identities in this globalizing world.

Grounded on these premises, the guiding research questions of this study are:

1. Which neoliberal challenges do socioeconomically underprivileged students majoring in English at a public university in Brazil report that they have faced in learning English and learning to become English teachers?

2. How do these students negotiate or overcome these challenges?

Below, I firstly present the research context, the methodological approach and the study participants. Secondly, I review what scholarly research states about neoliberalism and second language education as well as how a sociointeractionist perspective fundamentally based on dialogical practices can lead us to relate their constructs with the study scope. Thirdly, I discuss the data by bringing up the 
implications not only for the educational context where this study was carried out but also to other second language education programs where similar challenges are faced.

\section{Research Context}

This study belongs to a larger project entitled Language-System versus Language-Discourse: $A$ case study on the second language education of Letters-English undergraduates. ${ }^{1}$ Concerning the macro context of the investigated university, it is a public higher education institution, ranked among the fifteen best federal universities, and located in the central region of Brazil, which similarly to other public institutions, does not charge its undergraduates and graduates for any registration or tuition fees. ${ }^{2}$ By taking into account the micro context of the English second language program in question, it has two central goals. Firstly, it is responsible for prompting the undergraduates to use the English language as a social practice as historically and culturally situated subjects. Secondly, it also has the commitment to ground these teachers-to-be with learning/teaching theories necessary to involve them in practicum activities oriented to a context-based praxis. ${ }^{3}$

\section{Methodological Approach and Research Participants}

For this case study, with all its features and implications, a qualitative approach was the one which best addressed its scope. According to Denzin \& Lincoln (2000, p. 3), "qualitative research is a situated activity that locates the observers in the world. It consists of a set of interpretive, material practices that make the world visible", for it prioritizes the comprehension of the settings where the research is carried out, "attempting to make sense of the meanings people bring to them". Many scholars agree on the fact that qualitative case studies can be identified by their focus on the exploration and interpretation of individuals and their sociocultural contexts' characteristics, which could not be easily described by numbers. For them, these exploratory and interpretive features are also a way to guide researchers to the principle of generalizability, which enables them to learn from the specific context investigated and to relate their insights to a holistic perspective of the phenomenon studied. This principle does not imply that generalizations are built on accurate similarities among research contexts and their findings, but to how these places cope with the constituents of similar phenomena (Denzin \& Lincoln, 2000; Duff, 2014; Duff \& Anderson, 2015; Moreira \& Caleffe, 2006; Noor, 2008; Van Lier, 1988; Zainal, 2007). In addition to these important tenets, another principle that makes qualitative case studies even more valuable for second language education inquiries is the subjects' perspectives on the research scope, for their insights lead researchers to understand "reality and meaning as coconstructed through the dynamic processes of interacting with others and with the wider social, material and symbolic world" (Duff, 2014, p. 236). In view of that claim, another point to be considered is that, from interactional processes promoted by participants and researchers, the roles played by the latter are undeniably influential into case studies' development and outcomes. Duff (2014) states that qualitative researchers are oftentimes seen as a research instrument, a mediating coparticipant, or an actor in the research process. In other words, their interpretive work of the data goes beyond the theoretical framework adopted, for it comes along with their subjectivities on the issues under discussion as well as with their historical backgrounds that encouraged them to choose their research topic.

\footnotetext{
1 This project was submitted to the Committee of Ethics and Research, from the Feral University of Goiás, Brazil, and approved according to the document number 2.167.649 attested by the institution.

${ }^{2}$ Applicants interested in getting into the public federal universities have to do the yearly national entrance exam (Exame Nacional do Ensino Médio - ENEM).

${ }^{3}$ Source: https://le.letras.ufg.br/up/894/o/ppc ing jan2018.pdf / Course Pedagogical Program: Letters-English.
} 


\section{Sink or swim? Responsible situated agency constructed by socioeconomically underprivileged students of English in neoliberal Brazil}

Carla Janaina Figueredo

Regarding the focal group of investigation, these were the criteria used to define it:

1. This qualitative case study entailed the participation of students whose English background had been built solely in elementary and secondary public schools, excluding any sort of studies in private language institutions;

2. It also included those students who had never had overseas experiences with English nor had taken part in second language immersion programs;

3. It considered only the undergraduates who completed the program in four years (official length determined by the university), and it did not include the ones who, for any reason, either requested a leave of absence or dropped out of college.

4. It concentrated on the undergraduates who depended on the university to do their four-year second language program to both appropriate English and learn how to teach it.

As such, students who fulfilled these criteria were considered socioeconomically underprivileged for not having been able to afford additional English-medium education (e.g. within Brazilian contexts or abroad) before and during their time in college. By taking into account the criteria adopted, four undergraduates, out of twenty-five who started Letters-English in 2014, completed the program in 2017. From these four participants, one of them decided not to take part in the study by claiming that her several academic duties would not allow her special time for the research. Thus, this qualitative case study had its data generated from the participation of three undergraduates, identified after pseudonyms of their own choice, namely: Rafaela, Raul, and Felipe. In Table 1, I present some information taken from the participants' profile questionnaires. In addition to the general data, I summarize where they studied English as a foreign language (EFL), what their classes were like, and what profession they initially wanted for their lives.

\begin{tabular}{|c|c|c|}
\hline \multicolumn{3}{|c|}{ Research Participants } \\
\hline Rafaela & Raul & Felipe \\
\hline $\begin{array}{l}\text { - } \text { Age: } 23 \text { / Gender: female } \\
\text { - } \quad \text { Rometown: Goiânia/Goiás } \\
\text { - } \quad \text { She studied EFL in public } \\
\text { schools with emphasis on } \\
\text { grammar and translation. } \\
\text { - She really wanted to learn } \\
\text { English when a teenager, } \\
\text { but had no access to good } \\
\text { materials; English classes } \\
\text { were very short; studying } \\
\text { English was meaningless } \\
\text { due to focus on grammar, } \\
\text { vocabulary lists and lack } \\
\text { of social interactions. } \\
\text { She was always sure about } \\
\text { her choice to become a } \\
\text { teacher of English. }\end{array}$ & $\begin{array}{l}\text { - } \text { Age: } 20 \text { / Gender: male } \\
\text { Hometown: São Miguel do } \\
\text { Araguaia/Goiás } \\
\text { - } \quad \text { He studied EFL in public } \\
\text { schools with emphasis on } \\
\text { grammar and translation. } \\
\text { He really wanted to learn } \\
\text { English when a teenager, } \\
\text { but his classes were too } \\
\text { basic; activities were } \\
\text { inapplicable and there was } \\
\text { no social interaction in } \\
\text { English. } \\
\text { He wanted to be an } \\
\text { interpreter or a tourist } \\
\text { guide, not a teacher due to } \\
\text { the low social status of the } \\
\text { profession in Brazil. }\end{array}$ & $\begin{array}{l}\text { - } \text { Age: } 21 \text { / Gender: male } \\
\text { Hometown: Aparecida de } \\
\text { Goiânia/Goiás } \\
\text { - } \quad \text { Hece: Black } \\
\text { schools with emphasis on } \\
\text { vocabulary and gap filling } \\
\text { exercises. } \\
\text { He really wanted to learn } \\
\text { English when a teenager, } \\
\text { but always took part in } \\
\text { large groups where } \\
\text { indiscipline was a key } \\
\text { element to prevent } \\
\text { language learning and } \\
\text { practice. } \\
\text { He wanted to be a } \\
\text { journalist or an interpreter, } \\
\text { never pictured himself as a } \\
\text { teacher. }\end{array}$ \\
\hline
\end{tabular}

Table 1: Data source - Participants' profile questionnaire

With regard to the undergraduates' participation in the process of generating data, multiple instruments were applied in different stages, following what Denzin \& Lincoln state about the essence of 
qualitative research, that is, its triangulation, which offers researchers the possibility of blending "their own observations with the self-reports provided by subjects through interviews and life story, personal experience, and case study documents" (2000, p. 21). Besides a profile questionnaire (Appendix A), with both closed and open-ended questions from which I could gather the students' personal information and perspectives on prior English learning experiences, the data also came from the participants' oral and written productions where I could outline the first steps of their English appropriation process as well as their language skills development. These data came from their in-class interactions and assignments; most of them were generated during the disciplines' English Language levels 3, 4, 5, and 6 (throughout 2015 and 2016), when I was their teacher and had the opportunity to audio-record their oral-graded evaluations. In addition to crediting advantages to classroom observations of participants' language performance, I also agree with scholars concerning their efficiency aligned with data recording and note-taking, especially due to the possibilities of reexamining data originated in actual social interactions (Denzin \& Lincoln, 2000; Moreira \& Caleffe, 2006; Richards \& Lockhart, 2001). Therefore, a considerable number of participants' discursive practices was firstly registered in the questionnaire, observed in classroom participation, audiorecorded in oral exams, and written down in my field notes.

In order to promote more insights on their second language education, by the end of 2017 the participants were also asked to write about their learning/teaching experiences with English involving their communicative, sociocultural, and affective dimensions throughout the four-year program (see Appendix B). These narratives, one related to each year studied, were supposed to lead the undergraduates to critical reflections on their own trajectories so that they could both evaluate what they considered as positive or negative about them and possibly be able to project what they expected the future would hold for them. The inclusion of their narratives intended to accomplish what Pitman (2013, p. 31) claims about the relevance brought by this important research instrument, which is to appreciate "the power of the personal voice in educational research and its ability to provide information that other approaches cannot", or in Denzin \& Lincoln's words, turn the researcher into a "conduit for making such voices heard" (2000, p. 26).

To conclude the process of data generation, I also conducted a semi-structured interview with Rafaela, Raul, and Felipe. Unlike the traditional way of interviewing participants individually, I decided to coordinate it with all of them in just one meeting so as to create an atmosphere in which we could all have a conversation about the topics planned previously. The points highlighted throughout this interview were directly related to the participants' insights revealed on their narratives. Regarding the implications of this research tool, I agree with Fontana \& Frey (2000) on their argument that interviews are nothing less than a social event, collaboratively constructed by researcher and participants, whose negotiations are shaped by their subjectivities.

It is relevant to mention here that one particular element influenced this data generation substantially, namely, the removal of the textbook from the Letters-English Curriculum by the end of 2015. In view of that the study's participants had two different perspectives coloring their English appropriation process: the first two years of their majoring were guided by an imported textbook (2014 and 2015), and the last two years were marked by diverse source of materials chosen and organized by their professors (2016 and 2017). Given that the English Language classes were textbook-free from 2016 on, intercultural matters and second language critical studies gained more emphasis in classroom discussions, and that provided students with more opportunities to diversify their appropriation of English. Besides data generated in these classes (e.g. observations, oral practice recording, and note-taking), other ones came with the participants' first experiences in their two-year practicum (2016-2017), which I collected through nonparticipant observations, thorough notes on their teaching practice, and supervision of their lesson plans. 


\section{Sink or swim? Responsible situated agency constructed by socioeconomically underprivileged students of English in neoliberal Brazil}

Carla Janaina Figueredo

According to Van Lier (1988), these research instruments should count on researchers' familiarity with the language classroom context as well as with their intensive immersion in the registered data. In summary, generating data with purposes of promoting a scientific research, regardless of being qualitative or quantitative-oriented, can never be built on neutral stances. Based on this premise, qualitative case studies on second language education is not an exception. On the contrary, they are filled with beliefs and diverse identities from those who are in search of understanding not only what the social phenomenon reveals but also how it can be transformed.

\section{Socioeconomic Context}

Due to the complexities embedded in the term neoliberalism and how it connects to the context of my research scope, I divide this section into three parts: firstly, I present the concept of neoliberalism I have drawn on discussions promoted by Bockman (2013), Bourdieu (1998), Fairclough (2008), Holborow (2012), and Saad-Filho and Morais (2018); secondly, I narrow it down to the features of neoliberalism in Brazil; and thirdly, I conclude by making reference to some scholars who problematize the relationship between neoliberal forces and second language education.

\subsection{Neoliberalism seen from a four-fold perspective}

Although Bockman (2013), Bourdieu (1998), Fairclough (2008), Holborow (2012), and Saad-Filho and Morais (2018) come from varied fields of interest and adopt different ways to conceptualize neoliberalism, they agree on at least four basic definitions which lead us up to a better understanding of what a neoliberal force is, namely: an economy-oriented force; a capitalist force; an ideological force; and a discursive force. To start with, neoliberalism is rooted in an economic theory, which strenuously defends the lessening of the roles of a nation-state in order to strengthen "private property rights, free markets and free trade" (Holborow, 2012, p. 15). Based on this first premise, neoliberalism is conceived as a form of capitalism in which the state and its responsibilities towards society are rolled back in a way that multinational corporations and their socioeconomic interests exploit the so-called free market linked to globallyintegrated production. In other words, it should be understood as a system of accumulation, which is nothing less than a "stage, or mode of existence, of capitalism" (Saad-Filho \& Morais, 2018, p.56), and its continuous expansion restructures the interactions between local and global economies, reshaping, therefore, their economic, political, cultural, and social domains. According to Holborow (2012), the economic crisis faced by many countries in the late 1970s triggered a very strong belief that positioned the states as cumbersome economic players. The common sense was to put them aside so that the controllers of capital could shape not only the world economy but also its social dimension. For this reason, neoliberalism is also conceived as an ideology whose supporters put forward a one-sided representation of reality highly entrenched in contradictions between what it says and what it actually does. For instance, even though the cornerstone of neoliberal theory highlights the success of free market and capital production over states' interventions in economy, it is still the nation state which plays the role of a thermometer for international investments. By determining whether their markets are secure or not, how and where their labour forces should be used, state-run economies reveal how deep they are engaged in this economic tug of war. Furthermore, despite being believed as a right-wing ideology, Bockman (2013) claims that neoliberalism's most contradictory tenet lies on the adoption of its policies by left-political parties, generally associated with socialism ideals. Such inconsistencies turn neoliberal principles into a mythical mindset grounded on real world events, articulated by a dominant socioeconomic class but spread out as a world-view (Bockman, 2013; Holborow, 2012; Saad-Filho \& Morais, 2018). 
Nevertheless, all this manipulation of economy by means of privatization and liberalization of trade could never take place without a powerful instrument able to transform mere potentialities into concreteness, namely, discursive practices. In other words, discourse as the fourth element that causes to combine the foundations of neoliberalism not only serves it as a representational apparatus, but it is its main socially-embedded system that gives a tangible form to changes within social activities (Fairclough, 2008). This way, discourse should be viewed as a social practice or as a way discursive subjects act towards the world and their interlocutors, shaping them and the same time being shaped. According to Fairclough (2008), there is a dialectical relationship between discursive practices and social structures, for discourse can be expanded or constrained by all kinds of social interactions, no matter where they take place, in the institutional levels or in the interpersonal levels, or how they occur, verbally-oriented or not. In summary, since discourse contributes to filling the world with ideological meanings that both reflect and refract it (Vološinov, 1973), neoliberalism is, therefore, 'discourse-led' (Holborow, 2012, p. 22).

\subsection{Neoliberalism in Brazil}

When compared to countries in Latin America, Africa, and Eastern Europe, neoliberal policies in Brazil were consolidated after the end of dictatorship in 1985. Although the Brazilian way of trading with foreign partners was still marked by an excess of protectionism, there was an urgency for a more open economy able to address both the shifts in the international power relationships and the challenges of stabilizing inflation rates. Another fact that triggered neoliberal implementations was the ever-present combination of political corruption and very high state expenses, pointed out as being responsible for reducing funds for investments in industries, markets, and cutting-edge technologies, which consequently reinforced the disbelief on old paradigms (Amann \& Baer, 2002; Saad-Filho \& Morais, 2018).

Although many Brazilian economic shortcomings have been addressed by neoliberal measures (e.g. the permission of substantial inflows of foreign goods, services, and finance), Saad-Filho and Morais (2018, p. 68) highlight that "these inflows increased Brazil's vulnerability to balance-of-payments, exchange-rate, and financial crises". In the authors' opinion, the only consequences brought by neoliberal forces into the contemporary Brazilian society are that the governments "sought to limit the expansion of citizenship and shackle the emerging welfare state" (p. 68). In other words, despite the neoliberal reforms, the ultimate economic growth has been feeble, the distribution of income has worsened, and poverty has increased. It could be argued, therefore, that these neoliberal reforms should be blamed for the socioeconomic inequalities still common all over Brazil. Nonetheless, that would be a very simplistic thought. Brazil's painful history of colonization and slavery, two intertwined events that ravaged the country throughout three centuries, should also be considered. Their legacies can still be seen on the concentration of wealth in the hands of a rich small upper-middle class as well as on pervasive corruption policies, many of them adopted by both right-wing and left-wing governors that have successively ruled the country after it overcame dictatorship.

\subsection{Neoliberal forces and second language education}

Over the last years, many scholarly studies have discussed not only the impacts of a neoliberal agenda on language education but also to what extent neoliberal principles have reinforced implicitly or explicitly sociolinguistic inequalities in a range of different contexts (Flores, 2013; Kelly, 2013; Kubota, 2015, 2016; Kubota \& Miller, 2017; Park, 2012; Phillipson, 2003, 2008; Rivers \& Ross, 2013; Sayer, 2015). Flores (2013), for instance, makes a case for understanding neoliberalism both from its institutional side and the individual subject's perspective, which is inevitably moulded by neoliberal-grounded discursive practices. 


\section{Sink or swim? Responsible situated agency constructed by socioeconomically underprivileged students of English in neoliberal Brazil}

Carla Janaina Figueredo

In other words, he argues that the autonomy and flexibility supposedly given to neoliberal subjects cause them to be also corporatized at the same time they are induced to meet the market's needs.

In terms of language education, Phillipson $(2003,2008)$ states, regarding the roles played by English in a globalizing world: there is one major neoliberal global project for language education, which is providing English with a status of default language for intercultural/international communication in order to keep the power of Anglo-American nations over other countries. Furthermore, he also puts forward the argument that global or neoimperial English can be understood from three different but interdependent angles. The first one represents a lifetime project for those who dream to become part of an 'English world community', which is, in the author's opinion, an 'imagined community' hardly reached by most of its aspirants. The second one reveals English as a process being activated and expanded by its worldwide users responsible for putting its linguistic structures and embedded ideologies into practice. The third angle shows it as a product owned by specific communities of users geographically located. Given these three ways of understanding neoimperial English, Phillipson $(2003,2008)$ advocates that the language per se does not carry an imperialistic gene, but it becomes imperialistic once its speakers use it as a vehicle to convey and impose their domination ideologies.

Phillipson's contention is aligned with scholarly studies that emphasize how effective hegemonic values within the English language have been used to perpetuate colonial behaviors in former colonized countries (Kumaravadivelu, 2012; Makoni \& Pennycook, 2007; Mignolo, 2007, 2009, 2013; Penycook, 2001, 2007; Sayer, 2015). Besides still having to deal with their own colonization legacy, these nations are subdued to not only a linguistic invasion of English that undervalues their national languages but to a cultural imposition that leads many to willingly celebrate all kinds of Anglo-American representations. This way, Phillipson (2008) implies that the English expansion is directly or indirectly related to what Bourdieu (1986) names as cultural and social capitals, which can be derived from economic capital by means of appropriation and transformation. Contrary to common sense, Bourdieu (1986) takes up the position that either success or failure in financial, educational, and professional life is not a natural consequence of an individual's aptitudes. For the French sociologist, cultural competence, for instance, can be transmitted or given by one's family according to the availability of resources at their disposal. In other words, the more the family has to offer, the more their offspring will have to appropriate. If cultural capital (education and assets) is scarcely accessible in the family context, the socioeconomically underprivileged might end up either making strong efforts to acquire it or getting satisfied with what society can provide to them.

Other strong mindsets reveal how neoliberal ideologies control the trade of English as a linguistic, cultural, and social capital. One of them is the belief in the promise that acquiring English successfully will guarantee higher social status and the best job positions. The implications resulted from 'this promise' are discussed by Park (2011) when he draws parallels between what makes up the $21^{\text {st }}$ century neoliberal workers and those who pursue English as the language of 'opportunities' under neoliberal ideologies. The neoliberal worker as well as the learner of English are, according to the author, responsible for their own development and improvement, in addition to taking all the necessary initiatives capable to respond to demands imposed by a capitalist market.

Another pervasive mindset is the dichotomy native speaker/non-native speaker [NS/NNS] of English, which, notwithstanding many studies that problematize the myth of nativity, still contributes to blur learners of English' vision on their legitimacy as bilinguals (Figueredo, 2011; Faez, 2011; Park, 2012; Rajagopalan, 1997; Rivers \& Ross, 2013; Selvi, 2014). Overpowered by the idea that every single native speaker of English naturally holds a superior title of language authority, many second language learners 
worldwide are challenged by a colonial legacy currently conveyed by neoliberal ideologies. In other words, not only has the English language reached the five continents, but it has also spread out its western-based values, beliefs, and attitudes, which are controlled by the so-called 'owners of English' and seen by many as a 'gift' everyone should have (Vandrick, 2009). The effects resulted by this colonial legacy are oftentimes revealed in the social devaluation of learners' first languages and cultures (Kelly, 2013; Park, 2012), in the glorification of native speakers' fluency and proficiency regardless of who they are (Figueredo, 2011), in the learners' own conviction that their English language and teaching performances fall short of quality when compared to native speakers' (Kubota, 2015; Rivers \& Ross, 2013; Selvi, 2014), and in the discouragement many non-native speakers feel when it comes to fighting against social and linguistic discrimination (Kumaravadivelu, 2012, 2016; Munro, 2003).

By reflecting on the English language education scenario as a whole, Kumaravadivelu (2012, p. 22) points out what I also consider as a colonial legacy linked to neoliberal ideologies, namely, the process of marginalization and the practice of self-marginalization. In the author's view, "the former pertains to the ways in which the coloniality of the English language is exploited to maintain the authority of the center over the periphery. The latter refers to the ways in which the periphery surrenders its voice and vision to the center". In his article The Decolonial Option in English Teaching: Can the Subaltern Act?, Kumaravadivelu (2016) puts forward some elements that directly or indirectly support neoliberal principles in the English language education worldwide, namely: the way English-speaking countries impose the consumption of their theories and pedagogical methods to learners and teachers of English from peripherical countries; the way these 'consumers' end up reinforcing their marginalizing conditions when they are not able to recognize the value of their own production; the way this marginalization leads to a process of self-marginalization, especially when non-native speakers are confronted by the discourse-driven figure of the infallible native speaker; and finally, the way scholarly research produced in peripherical countries is marginalized for not having been written in neoimperial English. All these stances seem to present a scenario entangled in many opposing forces, and it is hard to believe there is a way out of it.

Nonetheless, I argue that Mignolo's decolonial thinking and its constructs such as 'delinking', 'relinking', 're-existing', and 'border thinking', are interesting pathways that can lead us to understand and confront second language education driven by neoliberal forces. Delinking, as stated by Mignolo (2009, 2013), means breaking connections with a Colonial Matrix of Power (CMP), which has been, for five centuries, responsible for structuring discourses and socioeconomic behaviors to ultimately turn them into dichotomies or ways to homogenize the world's perceptions of life (e.g. capitalism versus socialism, colonizers versus colonized peoples, imperial languages versus subaltern languages, etc.). According to Mignolo, delinking as a decolonial attitude does not act as a new paradigm that excels other ones (e.g. the modern and the post-modern epistemologies), but it works as an option which reveals other ways of thinking, doing, and dwelling "in the borders of local histories confronting global designs" (2013, p. 9). By delinking from this CMP, discredited linguistic and cultural communities have the chance to re-link to their own legacies and values, whose transformative power enables them to re-exist into a world also shaped by their presence and contributions. Taking into account these processes, Mignolo (2013, p. 9) asserts that decolonial thinking is nothing less than border thinking, which means "thinking of us". In other words, instead of just assimilating social creations that form a chasm between 'them and us' (e.g. the dichotomy native speaker versus non-native speaker of English), we should redirect our thoughts to our own potentialities and rediscover who we really are and what we really want to do with our modes of existence.

In the following section, I focus on the sociointeractionist constructs of language and subject, as theorized by the Circle of Bakhtin $(1973,1999)$ and on the conceptual discussions of agency according to 
Ahearn (2001) and Miller (2012). The aim is to explore their perspectives and how they can converse to one another so as to broaden our comprehension on what has entailed the case study in question.

\section{Theoretical Framework}

In choosing the main premises of Bakhtin and his $\mathrm{Circle}^{4}$ to discuss concepts such as language and subject, I have considered two major elements: their pioneering focus on how language is both socially constituted and interactionally produced; and their insights derived from a philosophy of language that enlightens my understanding on what makes a dialogical subject and on how one's agency works.

When it comes to language as a social practice, Bakhtin (1999) and Vološinov (1973) put forward the argument that the word is an ideological sign par excellence, and its capacity of both reflecting (conveying) and refracting (interpreting) meanings is the language basis for what they call dialogism. In other words, the dialogical nature of a language lies within the meaningful connections diverse utterances establish between them. These semantically-aligned utterances and the language users who produce them are both time and space-driven, that is, they are shaped by atemporal discourses (past, present, and futurebased ones) as well as by the spaces or social contexts they occupy. However, it is important to emphasize that the constitution of the Bakhtinian subject is not only grounded on their dependency in relation to their interlocutors and localities but also on their own abilities to create, change, and transform discursive practices arisen from their sociocultural experiences. That is why the dialogical subject designed by the Circle of Bakhtin is recognized by their unfinished and incomplete essence; since they are immersed in multiple discourses, they are always in constant rearrangement of their subjectivities. In addition to this incompleteness, the Bakhtinian subject is both responsible and responsive, which means they cannot escape their condition of 'non-alibi of being' (Bakhtin, 1999, p. 40); put in a different way, their human nature takes them to respond to their interlocutors (physically present or not, with words or with silence), for their mere comprehension of an utterance is itself an act of responsiveness, which implies their inherit responsibility to those who approach them meaningfully. In view of that, the climax of dialogism is, therefore, the inevitable interactions between the Self and the Other, their complementariness gained by convergent or divergent dialogical practices, and their capacities to promote volitional and evaluative stances, by which they express their will towards the surrounding discourses at the same time they judge them. In summary, the Bakhtinian dialogical subject is essentially agentive, and their acting simply means language by itself cannot do anything, but language users and the ways they deal with it can.

In discussing the complexities of the concept agency, Ahearn (2001) points out that no matter what one's research purpose is, or for what purpose one wants to understand agency, one should not reduce it to a simple free will that neglects its social nature, nor should one equate it with resistance as if it were its only aim, and, finally, nor should one even ignore it by suggesting that individuals per se are powerless before sociopolitical structures. In this sense, the author converses with the Circle of Bakhtin since they agree that agency is brought about by individuals' engagement in their social interactions, or in Ahearn's words (p. 112), 'agency refers to the socioculturally mediated capacity to act.' In spite of her awareness that her definition of agency cannot entail its several nuances, Ahearn (2001) also shares the Bakhtinian viewpoint that language underpins agency since she advocates that individuals actively construct and constrain context-based interpretations 'within a bounded universe of discourse' (p. 112). Bakhtin (1981) enhances this conception when he rejects neutrality in individuals' discursive practices and reaffirms that

\footnotetext{
${ }^{4}$ Although most of the publications are attributed to Bakhtin, the current scholarly literature has decided to credit most of their contents to him and his intellectual friends (e.g.Vološinov) who, throughout 1920's, promoted insightful discussions on the social nature of language. Their academic fellowship is widely known as Bakhtin and his Circle, a reference to knowledge they dialogically coconstructed.
} 
their discourses testify not only their existence but also their actions, for 'the word does not exist in a neutral and impersonal language [...] but rather it exists in other people's mouths, in other people's contexts, serving other people's intentions' (p. 294). Along with these principles, other Bakhtin's constructs help us understand two types of agency exercised by individuals and their contexts, namely, the centripetal and centrifugal forces (Bakhtin, 1981). The former is characterized by centralizing, hierarchizing, and monological actions; and the latter is recognized by its decentralizing, dispersing, and dialogical nature. Each one of these powers is also discursively formed and can influence the way individuals and their social contexts respond to what affects them. Hence, I take up the Bakhtinian viewpoint that it is from language, from its sociocultural and dialogical nature, that we can better understand how society and its actors relate to one another.

Therefore, when viewed as a discursive social practice, soaked up with subjects' identities, language does not only carry agency, but it is agency in itself. For instance, in drawing on Ahearn's discussions, Miller (2016) expresses caution when she reasons about the fine line between the discourses linked to the agentive second language learner and those connected to the neoliberal subject. When it comes to the agentive learner, the author stresses some of their attributes such as reflexivity, intentionality, and capacity to take actions. Although these are expected characteristics for a student to advance in their language skills, Miller (2016) draws an analogy between this excessive emphasis on the learner's autonomy and the neoliberal self, described as being 'activated, responsibilized, individualized, moralized, and/or freed' (p. 350). In other words, too much strength given to the learner's agency might gloss over neoliberal ideologies that shift the educational responsibilities of social institutions to individuals' actions alone.

Following these philosophical and critical reflections, I introduce the results of this case study in the next section. It aims to specifically provide an overview on how the participants exercised their agency towards their studies of the English language within sociohistorical contexts driven by neoliberal forces. I intend to discuss how the Other (the participants' interlocutors), how the spaces (the contexts they have taken part in), and how their own Selves have affected their responses and the (re)construction of their agency.

\section{Results: The participants' agentive profile}

In order to build the participants' agentive profile, I took into consideration the data generated by the questionnaire, the students' narratives, and the interviews, from which I could gather information on their English learning/teaching experiences (see section 3). In regard to these data, it is important to mention that, for Rafaela, Felipe, and Raul, the Other has played a central role in their sociocultural experiences, for their responsibility to respond to this Other has required from them agentive stands, marked by words, silence, agreements, disagreements, denials, awareness, unawareness, etc, to mention just a few. That means their responses have always taken place, one way or another. Their learning and teaching identities concerning the English language, for example, have certainly been moulded by the influence of the Other's discursive practices. Moreover, since the subject occupies specific discursive places, their subjectivities are not simply brought into these territories as additional components but are also influenced, modified, expanded, or constrained by the agency of these places, which is socially and linguistically mediated by other subjects' discourses (Miller, 2012). Thus, when it comes to how sociocultural and institutional spaces have affected the participants' learning and teaching processes of English, three specific periods should be highlighted.

The first one I am considering lies between the learners' initial studies of English, which started in elementary school, and their three years spent in secondary school before going to college. During this first 
period, English was a sort of imposed foreign language, for the Brazilian public Education did not provide them with other options. This 'imposition' acted as a regulating neoliberal force that conducted Rafaela, Felipe, and Raul to experience the linguistic and cultural perspectives of a dominant language, and that force did not only prevent them from getting to know other foreign languages but also subdued them to English influences outside the school. Besides that, Rafaela, Felipe, and Raul were also affected by the agentive principles of a teaching practice grounded in the Grammar Translation Method. Since their English classes were more actively inclined to restricting students to a structural rather than to a communicative view of English, the participants' learning identities had their agency channeled to ways their responses were found limited to negotiate changes with the spaces in question. Put in different terms, very little room was left for them to advance in their appropriation process of English.

The second period of agentive practices involves the first two years of students' majoring in English teaching. It is important to point out that their choice for the English program might have been influenced by their long trajectory of studies and experiences with this language, despite the availability of other options at the university such as French and Spanish programs. Other elements that should be considered are the places each one of these languages occupies in the Brazilian job market and what promises of a successful career each one of them has to offer. I have no intention to condemn the participants' choice for English, nor do I intend to deny their will to study it; nevertheless, if we take into account the neoliberal influence on second language education, English is undoubtedly the one that prevails. Those two years were also significant for these undergraduates because they did not only define their professional lives but were also immersed in a closer relationship with English, by which they could experience it in different ways. Their agency in relation to English was certainly reoriented since their appropriation process shifted to stages beyond the linguistic structures. Even though these first two years meant the beginning of a struggle to put English into different kinds of practice, and though Rafaela, Felipe, and Raul were subjected to the use of a textbook, they could act diversely to engage themselves in social interactions that reflected more their real life.

Given that, I have defined the third and the fourth years of students' majoring as the third period that reshaped once again their agency in relation to English, their interlocutors, the spaces they occupied, and their own Selves. Over this period, Rafaela, Felipe, and Raul did core subjects (e.g. English and Literatures of the English Language), which laid emphasis on critical studies and on decolonial practices, and started teaching at the University Language Center. I argue that this period was of great relevance because the undergraduates' views on English included some critical thinking that problematized many dichotomies related to the so-called neoimperial English as well as provided value to their legitimacy as bilinguals and authors of their second language. In addition, the first steps of their teaching practice certainly guided them to critical reflections when confronted by classroom challenges and probably led them to a more decolonial praxis.

As it can be noticed, agency is continuously reshaped by discursive practices. In view of this discussion that reveals how the Other, the Self, and the context are intertwined, I propose to define the study participants' agency as responsible situated agency, which is an attempt to emphasize their discourse-driven actions, organized and reorganized by their countless interactions that occur in result of their responsibility towards the Other, their local spaces, and their own Selves. My emphasis also lies on the potential autonomy this sociohistorically situated Self can exercise, for I concur with the Circle of Bakhtin that the dialogical subject is not a transcendent creature subdued by 'fate' but is able to challenge and overcome opponent forces (Bakhtin, 1999; Vološinov, 1973). 


\section{Sink or swim? Responsible situated agency constructed by socioeconomically underprivileged students of English in neoliberal Brazil}

Carla Janaina Figueredo

In the next sections, I discuss some of the data generated by the questionnaire, students' narratives, and interviews. In doing so, I expect to answer the research questions presented in the introduction of this article.

\section{Data Discussion}

The data presented for this discussion are divided into five categories that address, firstly, the neoliberal challenges faced by Rafaela, Felipe, and Raul (research question number 1); and, secondly, how these undergraduates responded to them (research question number 2). The categories related to the neoliberal challenges were designed as a way to reveal their significant occurrence in the participants' discursive practices conveyed by the research tools described in section 3 . I also considered the connections these discourses had with recent scholarly discussion on neoliberalism and second language education, based on what is presented in sections 4.1, 4.2, and 4.3. The categories which represent the students' responses to these challenges follow the concepts of the Circle of Bakhtin approached in section 5 and the construct responsible situated agency resulted from my discussion on the participants' agentive profile (section 6). Data generated by the study participants were produced in English, respecting their choice to use their second language to co-construct the present research; this way, data were transcribed according to students' original production, without any modification on their English.

\subsection{Neoliberal Challenge 1: Inequalities in getting the most out of English language education}

When it comes to neoliberalism, its effects are commonly represented by two sides: the ones who win, and the ones who lose, for not everyone is supposed to reach the same assets provided by society. For instance, if there is a massive concentration of economic, cultural, and linguistic capital at the hands of higher social class agents, consequently, there is also an exclusion of lower social class members from the contexts where they could access diverse material, cultural and linguistic commodities (Bourdieu, 1998; Saad-Filho \& Morais, 2018). This was the case of Rafaela, Felipe, and Raul, who, in this tug-of-war, experienced poor socioeconomic conditions that constrained their English appropriation before they started their university studies (See the questionnaire data on Table 1). The lack of important amounts of these capitals resulted in limited language skills, summarized in basic normative grammar knowledge associated with basic decontextualized vocabulary. When the participants were asked what their English was like when they entered college, they said:

Extract 1: "It was terrible. I did not know the structure of some very basic statements. I knew basic vocabulary such as numbers, colors etc." (Rafaela/Source: questionnaire)

Extract 2: "I could not communicate with accuracy. I only had some vocabulary and I could barely make sentences, not even to introduce myself." (Felipe/Source: questionnaire)

Extract 3: "I was not able to express myself easily because I did not have enough vocabulary or formal knowledge of pronunciation." (Raul/Source: questionnaire)

These data from the questionnaire reveal what can be considered a chasm between the socioeconomically underprivileged students who have to face the challenges of English-medium classes for the first time in their adulthood, and the privileged ones who reach the university context with communicative skills. Furthermore, the students' reports also make us look to the unequal paths formed by the Brazilian educational system when it comes to learning English in primary and secondary schools as 
opposed to private English language institutions. When Rafaela, Felipe, and Raul emphasize their inability to express themselves in English, they were offered very little to develop English as a social and dialogical practice (Vološinov, 1973); and it also indicates that, for them to become professional teachers of English, their efforts in a four-year program will have to make up for ten years of English studies which did not prepare them for college. In this neoliberal scenario, the neoimperial English conceived as a product (Phillipson, 2003, 2008) is nothing less than a linguistic capital which is not shared in its entirety as it should be. Here is the way the participants found to deal with the privations of their first year in college.

\subsubsection{Responsible situated agency: Ordinary sources of capitals can make a difference}

In view of their communicative limitations and urgent need to engage themselves in the appropriation process of English, Rafaela, Felipe, and Raul acted responsibly and responsively by taking advantage of what they had at their disposal, as can be read in the following extracts:

Extract 4: "At the university, I interacted with my classmates in English. I am an extrovert person, and I like to talk a lot. It was good to improve my language skills." (Rafaela/Source: Narrative 1)

Extract 5: "I used to read the dictionary, literally. I used to read words and their translation to Portuguese in the order they appeared. [...] I basically listened to songs in English and sometimes I tried to think and talk to myself in English." (Felipe/Source: questionnaire)

Extract 6: "I feel like when I started studying English at college, I spent most part of my days studying it. I used to watch as many Youtube videos as I could, I memorized many songs lyrics and I was really focused on my pronunciation. I also became friends with foreigners from the USA, what made my English improve very fast." (Raul/Source: Narrative 1)

According to Bakhtin (1999), responding to the Other, to surrounding places, and also to the own Self is what characterizes the dialogical subjects, their non-alibi of being, for once they are engaged in meaningful social interactions, there is no way for them to escape but to be responsible and responsive to their demands. What I learn from the responses provided by Rafaela, Felipe, and Raul is that they developed strategies aligned with their agentive profile and used what they had at their disposal to experience English as a relational language. In other words, their social interactions with classmates (Rafaela), with himself (Felipe), and with online friends (Raul), along with the reading of dictionaries, the listening of songs, and the watching of videos reveal that the students' agency was in fact triggered by both neoliberal challenges and the exigencies of their local context. That means the undergraduates' responsible situated agency was exercised in response to how they could overcome the demands for interactions with the Other and the requirements of the academic context. In doing so, these students could discursively affect their interlocutors in the spaces they occupied at the same time that they engaged themselves in their attempts to put English into practice. The use of simple materials shows us how the participants' initiatives try to work in their favor, and that discloses not only the desire to strengthen their second language Self but also the intention to move it forward despite the obstacles.

\subsection{Neoliberal Challenge 2: Poor linguistic capital narrows the path to diverse social capital}

As Bourdieu (1986) states, social capital is not naturally given but socially negotiated, and that social participation is often determined by other types of capital, especially the economic and the linguistic ones. In the researched context, Rafaela, Felipe, and Raul reveal that 'owning' the English language or being able to engage communicatively in diverse social interactions is usually the symbolic way to define 
who has the 'credentials' to take part in varied in-class activities. By following this idea of 'ownership', students often socialize with the ones who share similar degrees of proficiency in English, and their attitude ends up contributing to another symbolic distinction between groups of 'more proficient' students and 'less proficient' students. This classification of who 'owns' English and who does not usually causes the socioeconomically underprivileged to face displacement before more experienced speakers as well as disappointment for not being able to produce their second language in a wide variety of ways, as we can read in the next extracts:

Extract 7: "I was worried because the teacher just talked in English and I barely understood. When you do the "vestibular" [see note 3] no one says that you are supposed to know the language in order to start the course, so it was a little bit difficult for me at first. I also noticed that some students used to show off because they actually knew how to speak English." (Rafaela/Source: questionnaire)

Extract 8: "Before starting the course, I thought I knew something, but at the very first class when I saw many people who have been abroad speaking with fluency, I had an awful reality shock and I almost quit the course." (Felipe/Source: questionnaire)

Extract 9: "I did not like talking with the ones who were already fluent because I feared they would judge me." (Raul/Source: Narrative 1)

When Rafaela, Felipe, and Raul are prevented from widening their interpersonal relationships due to their poor linguistic capital in English, they reveal the powerful connection between 'having a cultural capital' and 'knowing English'. Rafaela supports this connection when she expresses her concern in not being able to follow what the teacher says and adds that '[...] some students used to show off because they actually knew how to speak English'. Felipe also expresses frustration when he compares his linguistic and cultural capitals with other classmates' who 'have been abroad'. The participants' dialogical practices also unveil how the English language has been legitimated as a worldwide linguistic capital. This legitimacy is unfortunately attached to the ones who think they 'own' English, and this mindset ends up shaping the agency of the space in question, for it determines who is eligible to speak and who is not, as we can read in Raul's report: 'I did not like talking to the ones who were already fluent because I feared they would judge me'. In summary, the unequal levels of investments in linguistic and cultural capitals do not only work out in favor of increasing social inequalities among the students, but they also heighten neoliberal forces attached to the learning/teaching processes of English in this particular academic space. Following are the participants' responses to the linguistic and social exclusion they were confronted by.

\subsubsection{Responsible situated agency: Going beyond the classroom walls}

It is important to highlight that the academic spaces in question are monolingual-oriented contexts, that is, apart from some international students, the overwhelming majority shares their first language, which is Brazilian Portuguese. In view of that, the main spaces for second language practices are the classrooms, where students are supposed to get as much involved as possible with English and its cultures. Even though Rafaela, Felipe, and Raul struggled to overcome their limitations in the social interactions throughout in-class English activities, they agentively found out other ways to resist the centripetal forces that centralized them within the boundaries of their first-year classes. The following excerpts reflect their efforts to both disperse the opposing currents and to open the way for their responsible situated agency:

\section{Extract 10: "Although I had much difficulty with the language itself, I usually tried to express} my opinions and I always participated on the activities suggested by the 
teacher. At the end of the first year, some colleagues and I decided to "try" to talk only in English outside the classroom." (Rafaela/Source: Narrative 1)

Extract 11: "Most of my classmates practiced the English language outside the classroom. As a result, I started talking in English with them in the courtyard, in the corridors, even when some students from different courses thought we did that to show off. [...] I believe that if we only had practiced English inside the classroom, we would be in a lower stage regarding our second language acquisition process." (Felipe/Source: Narrative 1)

Extract 12: "The fact that my friends and I tried our best to express ourselves in English influenced a lot on our acquisition process. [...] I found out that I had a lot to improve, but that did not break my confidence. Instead, I was really motivated." (Raul/Source: Narrative 1)

By reflecting on Rafaela's responsible situated agency, especially when she stresses her attempts to express her opinions as well as her participation '[...] on the activities suggested by the teacher', we see that her efforts are both to legitimize her agentive role in this language classroom and to have her participation recognized as a voice that also has the right to be projected. Likewise, feeling that the in-class interactions were not enough for their English appropriation, the persistence of Rafaela, Felipe, and Raul takes them to beyond the classroom walls so as to guarantee their dialogical practices and other discursive spaces to be occupied (e.g. talk only in English outside the classroom, talking in English in the courtyard, in the corridors). In doing so, their responsible situated agency turns into a centrifugal force that aims to tackle the hierarchizing power that often affects classroom interactions, such as the one we read in extract 8, when Felipe says: 'I thought I knew something, but at the very first class when I saw many people who have been abroad speaking with fluency, I had an awful reality shock and I almost quit the course.' Interestingly, it is the monological nature of a neoliberal academic context where English is not always shared equally that encourages Rafaela, Felipe, and Raul to respond in a dialogical manner responsible for including other interactants and redesigning their spaces. Although they are mistakenly considered as show-off by other undergraduates, their willingness to create new interactional spaces for their second language practices acted in favour of a reconfiguration of their prior agency. This scenario reminds me of Bourdieu's emphasis on the interdependence between social structures and social subjects as well as on how the former tends to dominate the latter (2008); however, it also reminds me that the Circle of Bakhtin goes beyond Bourdieu's perspective when it focuses on the agentive constitution of language and how powerful it can be when used by dialogical subjects seeking for egalitarian rights in their own local contexts (Vološinov, 1973). In other words, social transformation is mediated by language as discourse, but social transformation that includes equal distributions of capitals is triggered by dialogical subjects who stand up to centripetal forces such as neoliberalism. As Raul highlighted in his narrative, '[...] I found out that I had a lot to improve, but that did not break my confidence. Instead, I was really motivated". In conclusion, the perspective of a dialogical use of language (in this case, socioeconomically underprivileged speakers of English in a peripherical marginalized country) points to language as the means to make connections between social structures and social subjects work effectively to reach common goals.

\subsection{Neoliberal Challenge 3: The promise of English in the heart of Brazil}

The neoimperial English as a linguistic capital has been imposed by centripetal neoliberal forces as a way of supressing the importance of other languages so that English-speaking countries and their neocolonial capitalist interests can be benefited (Phillipson, 2008; Park, 2011). Given that, among many consequences of this neoliberal imposition is the promise that English is a gateway to a 'better life'. For a long time, this belief also marked considerably the study participants' perspectives on English as the following extracts can illustrate: 
Extract 13: "At the first year of my graduation, I had the impression that most of the students have when they are about to learn English: English is a global language, I can travel to any place and I will be able to communicate, I will get a better job etc. I did not care about English as power, for example, because I had never thought about it in this way. English represented a better way of life, an opportunity, and since I really liked the language (even before getting to know it), I felt like I was making a dream come true." (Rafaela/Source: Narrative 1)

Extract 14: "At the beginning of my studies, I used to see English as my passport to the USA. I also used to think that English was the only language I ever had to learn." (Raul/Source: Narrative 1)

Extract 15: "At the beginning of my graduation I felt annoyed, for there were not many subjects related to the English language." (Felipe/Source: Narrative 1)

The belief that English was a passport to all kinds of capitals (e.g. social and cultural capitals: 'English is a global language, I can travel to any place'; linguistic capital: 'I will be able to communicate'; economic capital, 'I will get a better job') came along with Rafaela, Felipe, and Raul when they started their university studies and, according to their reports, still persisted in the first terms. Based on the learners' narratives, it is possible to imply how this promise blurred their viewpoints by not allowing them to see English from different angles, such as a symbol of power and domination. For instance, Rafaela 'had never thought about it [English] in this way [as power]. Similarly, Raul considered English as the only foreign language worthy of learning; and the eagerness to be immersed in English was much more than a dream coming true, it was even the reason why Felipe felt so annoyed for not having all the classes taught in his second language. By considering that the participants' English learning experiences in elementary and secondary schools were grounded on grammar and vocabulary-centred classes (See Table 1), it is likely that this promise of English represented one out of many centripetal neoliberal forces that prevented Rafaela, Felipe, and Raul from engaging in dialogical discussions that problematized the roles of English in the contemporary Brazilian society. Needless to say, that these neoliberal forces are also entrenched by monological ideologies or one-sided representations (Holborow, 2012) which, in this case, are responsible for spreading ideas that English alone will live up to all students' expectations. Consequently, the general effects resulted by this promise are the prestigious and privileged positions occupied by the English language in the linguistic world market when opposed to the social status of other languages (e.g. French, Spanish, Italian, etc). At the same time, the so-called 'promise' of English also feeds contradictions between what it conveys through discursive practices, e.g. "English represented a better way of life, an opportunity' (Rafaela), "I used to see English as my passport to the USA" (Raul) and what it imposes to socioeconomically underprivileged students who have to appropriate a second language under colonial perspectives.

\subsubsection{Responsible Situated Agency: All languages are promising}

According to the participants' narratives written in the last year of their program, their responsible situated agency in relation to the promise of English flourished more intensively when they got more involved in the decolonial studies read and discussed in the English-based subjects. In addition to fostering their critical thinking concerning the roles played by English in a globalizing world, Rafaela, Felipe, and Raul also strengthened their relationship with their second language, which helped them realize that their appropriation process could be used as a 'place' where they could make themselves subjects (hooks, 1994). The following reports point out the dialogical discursive practices that now display the participants' different conceptions of English as well as their awareness of the effects decolonial discussions have brought into their academic lives: 
Extract 16: "Language involves people's feelings, beliefs, and it can change lives. In fact, it changed my life in personal and professional aspects. After intensifying my connection with the English language, now I am a person who values my own language and culture." (Rafaela/Source: Narrative 4)

Extract 17: "Since I took part in many discussions about issues related to identity and culture throughout the course, I have become an open-minded person. I used to think of English as a language spoken in the United States and in England and I used to be ignorant of other cultures." (Felipe/Source: Narrative 4)

Extract 18: "After all the critical discussions I had in English/about English I have become a critical person. I tend to reflect more about my practices related to English and also what regards me as a citizen. I know that the English language has many aspects and cannot be resumed in only one concept. It is a dominant language and it also oppresses other languages." (Raul/Source: Narrative 4)

The words 'I used to' and 'after' work as time markers in students' discourses. The first one regards their old beliefs which placed English in the center of their worlds, for example, when Felipe states that he '[...] used to be ignorant of other cultures'. The second one emphasizes the shift from a centripetal monological perspective that subdued them to the promise of English to a centrifugal dialogical understanding that opened their eyes to other frames of reference attached to the neoimperial English, such as Raul's claims that 'After all the critical discussions [...]', he now tends to 'reflect more about [his] practices related to English'. By acting responsively and responsibly throughout their participation in critical studies offered by the faculty, Rafaela, Felipe, and Raul got themselves immersed in a dialectics with the Other (e.g. articles on critical thinking, decolonial activities with professors and classmates, etc). In other words, their responsible situated agency towards the Other not only reshaped their viewpoints regarding themselves and their second language education program, but it was also co-constructed along with the agency promoted by the space in question, showing the complementariness between the Self and the Other (Bakhtin, 1999). The results of these dialogical practices, also viewed here as a diverse meaning-making process, caused the participants to conceive language as a life-changing means, (e.g. Rafaela: 'Language involves people's feelings, beliefs, and it can change lives'). With this meaning into students' perspective, English was placed in a discussion that enabled them to value their own language and culture (Rafaela), to become an open-minded person in relation to other cultures (Felipe), and to exercise their criticality (Raul), thus, making them aware of their citizenship in face of the English oppression over other languages. The students' agentive profile also demonstrates how they responded to textbook-free classes that focused more on the Englishes and their roles around the world rather than on Anglo-American values and cultural patterns. It should be considered, therefore, that the participants' willingness to draw themselves to decolonial discussions can lead them to respond more critically to their teaching practice. In doing so, chances are that they will act to demystify the promise of English and consequently enlighten their students to the promising character of other languages and cultures.

\subsection{Neoliberal Challenge 4: The haunting of the neoliberal self}

The neoliberal self has been characterized as self-directing, self-regulating, self-determined, autonomous, accountable, and free to make choices (Park, 2010; Flores, 2013, Miller, 2016). In the viewpoints of the mentioned scholars, this apparent 'given freedom' is actually a façade that hides the manipulative actions of a socioeconomic system that does not want to take any responsibility for societal failures. This concept can be better understood in the extract 19, when Rafaela is asked to evaluate the four-year second language education program she did. Rafaela's discourse signals to how the neoliberal self affects the understanding of her communicative limitations in English. 


\section{Sink or swim? Responsible situated agency constructed by socioeconomically underprivileged students of English in neoliberal Brazil}

Carla Janaina Figueredo

Extract 19:

Rafaela: For me it was, it was enough, but I think it was enough because of PIBID [Institutional Funding Program for Teaching Careers] and Centro de Línguas [University Language Center] - because, from this year on, the beginning of the year, I think I improved a lot, so I think it helped, but concerning the graduation, the course itself, I think it was good, but ...., I don't know, I feel like, it could be better, you know, I think it's because of me, I worked a lot at the first and the second year of college, so, I think I..., could have, eh, how can I say this?, ... I don't know, enjoyed the things, you know, that we saw at the beginning. [...] So, the problem I think it's me. [...] And that's why I make so ridiculous mistakes, because it has to do with the..., beginning. and thanks God that I'm teaching English 1 and 2, so I'm, now I'm learning the basic rules again! (Source: Interview)

Although Rafaela has a positive opinion on her majoring in English (e.g.'concerning the graduation, the course itself, I think it was good'), she takes full responsibility for not having been able to devote herself to the first years in college. In her perspective, having to work was harmful to her learning and that resulted in linguistic gaps she is still trying to fill in: '[...] I feel like, it could be better, I think it's because of me, I worked a lot at the first and the second year of college, so, I think I could have enjoyed the things that we saw at the beginning.' In blaming herself, Rafaela reveals the traits of what Miller (2016) describes as the neoliberal self, which discursively channels a responsibilized and individualized agency into their own Self. For instance, when Rafaela states that she thinks it was 'she' who prioritized work over her early English studies, Rafaela emphasizes that her agency did not depend on the Other and their social contexts to be activated: 'I worked a lot' [...] 'So the problem I think it's me' [...] 'And that's why I make so ridiculous mistakes'. That said, Rafaela's self-evaluations do not only recall the neoliberal self, but they also reveal how oppressive it is, representing here a centripetal force to those who have to juggle their second language education and their needs to work. Grounded on Bourdieu (1986), Miller (2016), and Park (2011), this apparently 'freed self', totally responsible for their actions, is utopic and only works to please the interests of a neoliberal society. As it could be learned from the Bakhtinian subject, their unfinished and incomplete nature requires constant interactions with interlocutors and spaces that both affect their identities and leave room for their agency. Hence, Rafaela could not study harder because her financial needs demanded more time from her, which means she was not 'the problem'. This way, it is crucial that classroom discussions focus more on how to undermine the figure of this neoliberal self, but, at the same time, emphases should also be given to the fact it does not eliminate students' responsibility and responsiveness to their Other, their social contexts, and their Selves.

\subsubsection{Responsible Situated Agency: Conquering spaces at the university context}

Despite the haunting of the neoliberal self that responsibilized Rafaela for her low achievements at the beginning of the second language education program, her responsible situated agency can be seen in her attitude to apply for important positions in teaching enhancement programs provided by the university:

Extract 20: During the first year, it was not good, for I had to work in a shopping mall and I did not have time to study. However, from the second year on I enjoyed many things that the university provides. I was a monitor, at Núcleo Takinahaky, I entered to Pibid and then I entered to Centro de Línguas. [...] I have some colleagues who do not know how to make a lesson plan and it is not their fault, they did not have the same opportunity as I have to be part of these two programs (PIBID and CL). (Rafaela/Source: Narrative 4) 


\section{Sink or swim? Responsible situated agency constructed by socioeconomically underprivileged students of English in neoliberal Brazil}

Carla Janaina Figueredo

When acting as a monitor of English in an indigenous program and taking part in two institutional funding programs for teaching careers, one in a public school and the other one in the University Language Center, Rafaela indicates that her responsible situated agency aimed to increase her sociocultural and teaching experiences with the English language; her initiatives resulted in her 'enjoyment' of the local programs. It is important to mention that, although the university programs aim to enhance the interns' teaching performance long before they get their degrees as professional teachers, they are not able to include all the undergraduates, and that is why Rafaela feels privileged for having succeeded in becoming part of them. By conquering her own space into what the institution offers, Rafaela's efforts to advance in the academic studies and professional practices can be understood as centrifugal forces that worked not only to reshape her identity as a learner/teacher: 'thanks God that I'm teaching English 1 and 2, so I'm, now I'm learning the basic rules again!' (extract 19) but also to restructure the configuration of these programs by including more socioeconomically underprivileged students. According to Miller (2012, p. 447), "the agency of spaces becomes efficacious as individuals participate in practices which (re)constitute the reality of and the social meanings attached to such spaces.'

As for Raul, his agentive participation as a teacher student in the Language Center also resulted in contributions to his own initial teaching practice and to the places he occupied in this context:

Extract 21: The experiences I had at Centro de Línguas were really important in my practice as a teacher. I believe that I will be able to use many of the material I developed and adapted while working there in other institutions. (Raul/Source: Narrative 4)

In emphasizing his pedagogical work and its influence in different contexts, Raul reflects what Bakhtin (1999) states about the dialogical subject and their complementing nature in relation to the Other they interact with and the spaces they encounter. However, not only is the participants' responsible situated agency able to affect the Other and the social spaces but, by acting towards them, it is also able to transform the students' Selves. That can be noticed in Felipe's experience with another university program, by which he could change his perspectives on the way he saw his second language abilities.

Extract 22: I had the opportunity of visiting the English Club, which was a conversation group guided by some native speakers of English. As I could talk to them and understand what they said, I felt extremely fulfilled. Regarding my colleagues at college, I felt like we were at the same level. I stopped feeling inferior to them as I used to feel during my first year in college. (Felipe/Narrative 3)

As stated in section 4.3, there is a fine line between neoliberal forces and the English learning/teaching spheres in marginalized countries, which becomes especially noticeable in the dichotomy [NS/NNS] of English and in the unequal access students have to cultural and linguistic capitals. Felipe's narrative 3, written in regard to what he did throughout the third year, highlights the outcomes of his responsible situated agency towards the English Club. By facing the challenges of this academic context, Felipe's interactions led him to confront a 'self-marginalization' trait that positioned his Self as being illegitimate before the so-called language authority (native speakers) and inferior before the ones who had oversea experiences with English (his colleagues at college, see also Extract 8). In my viewpoint, Felipe's feelings of fulfillment and self-confidence gained through his experiences in the English Club were not only built up by the realization of his effective bilingualism but also by his confrontation with oppressive neoliberal ideologies conveyed by marginalizing discourses. Besides that, Felipe's responses also signal to the need of more reflections on the roles played by the local academic programs: to what extent are they working as centrifugal/decentralizing/dialogical forces responsible for encouraging the agency of socioeconomically 
underprivileged students affected by neoliberal interests? Felipe's reconstructed Self should not be an isolated case.

\subsection{Neoliberal Challenge 5: Legitimacy is never the same among speakers of English}

The legitimate speaker/user/teacher of English is often built by discursive practices that strengthen the powerful figure of native speakers. The power of these discourses gradually turns into financial benefits for the English learning/teaching industry guided by central countries, such as England, USA, Canada, Australia, etc. (Kumaravadivelu, 2012). This neoliberal challenge can be noticed in the data concerning the participants' English teaching experiences throughout their last year in college. As it follows in students' narratives, extracts 23,24 , and 25 reveal the undergraduates' uncertainty of their legitimacy as speakers/teachers of English:

Extract 23: "At some point, I can say that I walk hand in hand with English because I work with it and I use it every day. On the other hand, I am not one hundred percent confident because I know I have a lot to improve concerning the language itself." (Rafaela/Source: Narrative 4)

Extract 24: "I think I need more practice in order to be a legitimate teacher, I don't know about my future career, what's going to happen." (Felipe/Source: Interview)

Extract 25: "Many times I felt like what I was studying at college was very far apart from my reality as both student and teacher [...] we students were asked to teach in a way that is unmanageable depending on the context we are teaching (like public schools, for example), what brought anxiety to me and my colleagues." (Raul/Source: Narrative 4

As it can be seen, there seems to be a lack of confidence reflected on the participants' desire for 'more practice' (Felipe), on their need to 'improve' their English (Rafaela), and on the 'anxiety' felt in face of teaching challenges (Raul). Their insecurities related to their little teaching experience is understandable, and their willingness to make progress and become better learners and teachers is certainly noteworthy and should be kept throughout their professional careers. However, these uncertainties can also mirror what Kumaravadivelu (2012) states about the effects of marginalization in the so-called peripherical countries, where neoimperial English is used to subdue them to the English-speaking world that agentively discredits the legitimacy of those who speak English as a second language. Following this marginalized condition, Rafaela, Felipe, and Raul reveal traits of self-marginalization, by which they demonstrate a certain skepticism on the value of their teaching practice: 'I am not one hundred percent confident' (Rafaela); 'I need more practice to be a legitimate teacher' (Felipe); 'Many times I felt like what I was studying at college was very far apart from my reality as both student and teacher' (Raul). In these extracts, the participants tend to surrender to a centripetal discourse that questions the 'quality' of their English and the 'effectiveness' of their teaching. Taking into account the neoliberal principles that interfere in second language education where English is the leading character, these data and other scholarly research underscore a supposed everlasting gap that can never be bridged, no matter how long a non-native speaker studies the language or teach it. In other words, for the neoliberal forces that support these 'gaps', the never-ending practice is not enough to please the markets (Figueredo, 2011; Jorge, 2009; Kelly, 2013; Kumaravadivelu, 2012; Mateus, 2018; Park, 2012; Park, 2011; Rajagopalan, 1997; Selvi, 2014).

7.5.1 Responsible Situated Agency: Legitimacy comes with teaching practice

Unlike other careers in education, such as Brazilian Portuguese, Mathematics, Literature, Biology, etc., teaching English in Brazilian regular schools usually demands extra efforts, and struggling for linguistic 
legitimacy and credibility is one of them (Jorge, 2009). After the participants completed their four-year program to get a degree in English teaching, I asked them throughout the interview if they viewed themselves as legitimate teachers of English. The following extract gives evidence of their responsible situated agency regarding this issue:

\section{Extract 23:}

Researcher: Do you consider yourselves legitimate teachers of English?

Rafaela: Now I do. Last year I didn't. Now I do. Now I can say, 'Oh, I teach English, and I'm a teacher now', because I had the opportunity to be a teacher, to have my class. You know, although we had the supervisor, the mentor, we manage our students in our class, we control, we guide them, so, this year was very important to my formation.

Raul: $\quad[. .$.$] I feel like, when you teach, because you get much more, you dedicate much$ more than when, when you are a student, and, yeah, but I still, I see myself, like, as a teacher, not only as an English teacher or a French teacher. So, yes, I get, I consider myself a legitimate, yes, a legitimate teacher.

Felipe: [...] The lack of experiences, right, I think like, two years and a half is not enough, and especially because I have only taught here, and I, I didn't get in touch with other contexts, and here is like, as people say [Rafaela: a bubble!], it's a bubble, because everything is available for you to use, and in many places out, out there, there are not that, that many materials available for us to use. It's like, you only have the board and the coursebook, and do with that! So, I think, I need this reality before assuming myself as a legitimate teacher. (Source: Interview)

Rafaela and Raul share the opinion that their teaching practice in the University Language Center legitimizes their teaching identities. Both their teaching experiences and the space where they occurred represented a centrifugal force since they worked dialogically as a decentralizing power by which these undergraduates exercised their responsible situated agency towards the benefit of the Other (e.g their own students, workmates, etc) and their Selves (e.g. the ongoing construction of their teaching identities). By taking into account what Rafaela says in relation to herself: 'I teach English, and I'm a teacher now', followed by what Raul states: 'I see myself, like, as a teacher, not only as an English teacher or a French teacher', teaching itself does not only mean conveying knowledge on how the English language works, but it also means dialogical practices that can embrace different social voices and boost the self-confidence of socioeconomically underprivileged students. Having their own groups conducted by their own lesson plans assures Rafaela and Raul of the legitimacy they need to put into practice what they experienced in their second language education program, such as building criticality on the positive and negative aspects of learning English from a textbook and from decolonial perspectives. On the other hand, Felipe demonstrates his responsible situated agency when emphasizing his desire to know other teaching contexts and face different challenges as opposed to the ones he already experienced at the Language Center: '[...] here is like, it's a bubble, because everything is available for you to use, and in many places out there, there are not many materials [...] you only have the board and the coursebook, and do with that! So, I think, I need this reality before assuming myself as a legitimate teacher'. In this way, Felipe agentively stands for broadening his experiences in regular schools and, in doing so, he projects his legitimacy as a language teacher once he is able to share his English education with those outside the language institution spaces. His response also displays a dialogical perspective that can potentially confront neoliberal ideologies set in other second language learning contexts. 


\section{Sink or swim? Responsible situated agency constructed by socioeconomically underprivileged students of English in neoliberal Brazil}

Carla Janaina Figueredo

After discussing some data collected for this case study, I present in section 8 my final reflections on its contributions.

\section{Conclusion}

Grounded on what the data reveal, on what scholarly research discusses in terms of neoliberalism and second language education, and on the Bakhtinian perspectives for the dialogical agentive subject, I have divided the contributions of this case study into two interdependent facets: the theoretical and the empirical.

The theoretical contributions have come especially with the alignment between the Bakhtinian tenets on the responsive, responsible, and dialogical subject and the participants' agentive profile that demonstrates historically and socioculturally situated responses in face of constant centripetal neoliberal forces. That is, despite having their access to different types of capitals restricted by social and economic structures, the study participants counteracted, firstly, by following a non-alibi of being principle, and secondly, by resisting a centralizing power that aims to keep them in socioeconomically underprivileged conditions. As such, Bakhtin and his Circle bring a crucial contribution when they put forward that language is the central social dimension where sociohistorically situated subjects are shaped. In other words, throughout the subjects' dialogical interactions, their identities, contexts, and languages are also mutually shaped. Therefore, in Bakhtinian perspectives, it is worthy of notice that social transformation does not only occur when an entire social class fights against unfair sorts of capital accumulation (Bakhtin, 1973), for acting dialogically within micro localities also has potentialities to contribute to sociocultural changes. These discussions along with the participants' responsible situated agency are, in my viewpoint, an important theoretical contribution of this case study for second language education research.

The social and educational implications pointed out by the data represent the empirical contributions of this case study. For instance, Kumaravadivelu (2016) states that the subalterns can speak and write, but he calls into question the existence of possibilities for them to act. I argue that they can, and that one of the triggering ways to empower students to counteract neoliberal challenges, marginalization, and self-marginalization is their engagement in decolonial thinking or border thinking, the 'thinking of us', as proposed by Mignolo $(2009,2013)$ and timidly accepted by Kumaravadivelu in his text. The study participants' responsible situated agency always occurred throughout their four-year program, but it teaches us that once they got actively involved in decolonial discussions in the last two years, their viewpoints and attitudes towards the English language learning/teaching processes revealed a much more dialogical agency concerned with the sociocultural and linguistic transformation of their Selves, the Other, and the local contexts. By taking the participants' responsible situated agency into account, I highlight the following empirical lessons we can learn from this proactive research.

Firstly, undergraduates who need to appropriate English in the course of their four-year program should be encouraged by dialogical discursive practices which legitimize their language abilities and ongoing appropriation process as being valid. That requires an intensive agency from the faculty as well, for besides being a symbolical force able to promote changes in their social context, they can influence the classroom dimension and its power dynamics. When responsible situated agency is dialectically exercised by both parts, the undergraduates are guided to find their own ways to produce discourses that confront prejudice, exclusion, and self-marginalization.

Secondly, decoloniality should be exercised along with self-decoloniality in order to redefine subjects marked by a history of colonization and coloniality and, consequently, redesign the discursive 


\section{Sink or swim? Responsible situated agency constructed by socioeconomically underprivileged students of English in neoliberal Brazil}

Carla Janaina Figueredo

spaces they occupy. Decoloniality is concerned with economic justice and global equality and lays great emphasis on the macro level. It should occur between society and us by decolonial practices that aim to delink our social blemishes from colonial legacies. Nevertheless, I suggest that, besides caring for the collective, we should also care for the micro level and be more responsive and responsible to the selfmarginalized individual. In other words, when my-self realizes that their sociocultural constitution is so valuable as any other one, and when my-self learns that by being bilingual we are in fact able to explore different linguistic and cultural worlds, out of our own aquarium, that means we are embedded in a selfdecoloniality process. Once affected by the agency of discourses that demystify marginalization and selfmarginalization, self-decoloniality as a centrifugal force crosses the subject's borders, enabling them to adopt dialogical agentive positions that create new symbolic spaces where their language and teaching practices are valued.

Thirdly, diverse forms of responsible situated agency should be stimulated by second language education programs so that undergraduates (privileged or underprivileged) see themselves from sociocultural perspectives that respect who they are and what they produce in relation to the Other (e.g. the recognition of their English as a legitimate language). In Brazilian contexts, for instance, that would help students to dissipate a sort of street dog complex ${ }^{5}$, which oftentimes pass through their discursive practices colored by marginalized and self-marginalized traits. Decoloniality and self-decoloniality are, therefore, a powerful option to build on common places for equal rights.

In drawing on Mignolo's constructs of delinking, by which we disconnect ourselves from the coloniality of English-speaking countries; relinking, by which we reconnect ourselves to the valuable representations of our language and cultures; and re-existing $(2009,2013)$, by which we act to reconstruct our discourses and spaces, I advocate for the following points that would benefit the investigated context and probably other similar sociocultural spaces:

\begin{tabular}{|l|l|}
\hline \multicolumn{1}{|c|}{ Delinking from... } & \multicolumn{1}{|c|}{ Re-existing to... } \\
\hline $\begin{array}{l}\text { the oppressive dichotomy native speaker versus non- } \\
\text { native speaker. }\end{array}$ & the recognition of how important being a bilingual is. \\
\hline $\begin{array}{l}\text { a second language education grounded on the standards } \\
\text { and ideologies from hegemonic English-speaking } \\
\text { countries. }\end{array}$ & $\begin{array}{l}\text { a second language education that also projects the } \\
\text { voices from the South as well as the legacy inherited } \\
\text { from Brazilian sociocultural elements. }\end{array}$ \\
\hline $\begin{array}{l}\text { the agentive neoliberal self. } \\
\text { discursive practices that reinforce marginalization and } \\
\text { self-marginalization of second language learners and } \\
\text { teachers. }\end{array}$ & $\begin{array}{l}\text { a responsible situated agency that builds up second } \\
\text { language education as a way to overcome neoliberal } \\
\text { forces and fight against social inequalities. }\end{array}$ \\
$\begin{array}{l}\text { the faculty and all the undergraduates, which focuses on } \\
\text { decolonial and self-decolonial practices to oppose the } \\
\text { reproduction of the status quo. }\end{array}$ \\
\hline $\begin{array}{l}\text { discursive practices that ignore the legitimate identities } \\
\text { second language. }\end{array}$ & $\begin{array}{l}\text { the option of 'swimming', not 'sinking' or surrendering } \\
\text { to the opposing currents, which means promoting } \\
\text { decoloniality and self-decoloniality to deconstruct the } \\
\text { street dog complex. }\end{array}$ \\
\hline
\end{tabular}

Table 2: Study implications for the investigated context

\footnotetext{
${ }^{5}$ The expression street dog complex was coined by the Brazilian writer Nelson Rodrigues. On a chronicle published by Manchete Esportiva Magazine on May $31^{\text {st }}, 1958$, he defined the term as a voluntary feeling of inferiority that Brazilians have when they compare themselves to the rest of the world.
} 
In conclusion, we should never underestimate our students' capacity to negotiate or even overcome challenges that seem to be unsurmountable. The number of overcomers, however, should be increased, and it is crucial that their teachers lead them to grapple with socioeconomic injustice through dialogical educational practices filled by multiple social voices and evaluative stances. In doing so, students are taught how to 'swim'. It is not a matter of letting them be led by the currents, but how they should exercise their agency to tackle them. The subalterns can act, so we, as educators, ought to engage them in ways that turn their actions into effective results for their localities, for their own sake, and for the sake of the Other. Once they learn how to swim in the neoliberal ocean, being able to avoid sinking, they will just keep swimming and teaching others how to swim too.

\section{References}

Ahearn, L. M. (2001). Language and agency. Annual Review of Anthropology, 30, 109-137.

Bakhtin, M. M. (1981). The Dialogic Imagination: Four Essays. Austin, TX: University of Texas Press.

Bakhtin, M. M. (1999). Toward a Philosophy of the Act. Austin, TX: University of Texas Press.

Base Nacional Comum Curricular. (2018). Retrieved from http://basenacionalcomum.mec.gov.br/

Block, D., Gray, J., \& Holborow, M. (2012). Introduction. In Block, D., Gray, J., \& Holborow, M. (Eds.), Neoliberalism and Applied Linguistics (pp. 1-13). New York, NY: Routledge.

Block, D. (2012). Economising globalisation and identity in applied linguistics in neoliberal times. In Block, D., Gray, J., \& Holborow, M. (Eds.), Neoliberalism and Applied Linguistics (pp. 56-87). New York, NY: Routledge.

Bourdieu, P. (1986). The forms of capital. In Richardson, J. (Ed.), Handbook of Theory and Research for the Sociology of Education (pp.241-258). Westport, CT: Greenwood.

Bourdieu, P. (1998). Acts of resistance: Against the new myths of our time. Cambridge, CB: Polity Press.

Bourdieu, P. (2008). A economia das trocas linguísticas: o que falar quer dizer. São Paulo, SP: Editora da Universidade de São Paulo.

Denzin, N. K. \& Lincoln, Y. S. (2000). Introduction: The discipline and practice of qualitative research. In Denzin, N. K. \& Lincoln, Y. S. (Eds.), The Sage Handbook of Qualitative Research. (pp. 1-32) Thousand Oaks, CA: Sage Publications.

Duff, P. (2014). Case study research on language learning and use. Annual Review on Applied Linguistics, 34, 233-255.

Duff, P. \& Anderson, T. (2015). Case study research. In J. D. Brown \& C. Coombe (Eds.), The Cambridge Guide to Language Research. (pp. 112-118) New York, NY: Cambridge University Press.

Faez, F. (2011). Reconceptualizing the native/non-native speaker dichotomy. Journal of Language, Identity, and Education, 10, 231-249.

Figueredo, C. J. (2011). O falante nativo de inglês versus o falante não-nativo: representações e percepções em uma sala de aula de inglês. Linguagem \& Ensino, 14 (1), 67-92.

Flores, N. (2013). The unexamined relationship between neoliberalism and plurilingualism: A cautionary tale. TESOL QUARTERLY, 47(3), 500-520. 
Fontana, A. \& Frey, J. H. (2000). The interview: from structured questions to negotiated text. In Denzin, N. K. \& Lincoln, Y. S. (Eds.). The Sage Handbook of qualitative research. (pp. 645-672) Thousand Oaks, CA: Sage Publications.

Holborow, M. (2012). What is neoliberalism? Discourse, ideology and the real world. In Block, D., Gray, J., \& Holborow, M. (Eds.) Neoliberalism and Applied Linguistics. (pp. 14-32) New York, NY: Routledge.

hooks, b. (1994). Teaching to transgress: education as the practice of freedom. New York, NY: Routledge.

Jorge, M. L. S. (2009). Preconceito contra o ensino de língua estrangeira na rede pública. In Lima, D. A. (Ed.), Ensino e Aprendizagem de Língua Inglesa: Conversas com especialistas. (pp. 161-168), São Paulo: SP, Parábola Editorial.

Kelly, W. (2013). Applying a critical metatheoretical approach to intercultural relations: The case of U.S. Japanese communication. In Agarte, M. K. (Ed.) The Global Intercultural Communication Reader. (pp. 972-1016), Taylor \& Francis Group.

Kubota, R. (2015). Race and language learning in multicultural Canada: Towards critical antiracism. Journal of Multilingual and Multicultural Development, 36, 3-12.

Kubota, R., \& Miller, E. R. (2017). Re-examining and re-envisioning criticality in language studies: Theories and praxis. Critical Inquiry in Language Studies, 14, 129-157.

Kumaravadivelu. B. (2016). The decolonial option in English teaching: can the subaltern act? TESOL QUARTERLY, 50, 66-85.

Kumaravadivelu, B. (2012). Individual identity, cultural globalization and teaching English as an international language: The case for an epistemic break. In Alsagoff, L., McKay, S., Hu, G. \& Renandya, W. (Eds.), Teaching English as an International Language: Principles and Practices. (pp. 9-27), New York, NY: Routledge.

Makoni, S., \& Pennycook, A. (2007). Disinventing and reconstituting languages. In Makoni, S., \& Pennycook, A. (Eds.), Disinventing and Reconstituting Languages. (pp. 1-41), New York, NY: Multilingual Matters.

Mateus, E. (2018). Diálogos entre a universidade e a escola na trans(formação) de professores de línguas. In Freitas, C. C., Brossi, G. C., Silva, V. R., \& Hermes Junior, A. T. (Eds.) Diálogos entre a universidade e a escola na trans(formação) de professores de línguas. (pp. 23-50), Anápolis: GO, Editora UEG.

Mignolo, W. D. (2009). Contexts: Coloniality is far from over, and so must be decoloniality. Afterall: $A$ Journal of Art, Content and Enquiry, 43, 39-45.

Mignolo, W. D. (2013). Geopolitics of sensing and knowing: On (de)coloniality, border thinking, and epistemic disobedience. Confero, 1 (1), 129-150.

Miller, E. R. (2012). Agency, language learning, and multilingual spaces. Multilingua, 31, 441-468.

Miller, E. R. (2016). The ideology of learner agency and the neoliberal self. International Journal of Applied Linguistics, 26 (3), 348-365.

Moreira, H. \& Caleffe, L. (2006). Metodologia da pesquisa para o professor pesquisador. Rio de Janeiro, RJ: DP\&A Editora. 
Munro, M. J. (2003). A primer on accent discrimination in the Canadian context. TESL Canada Journal/Revue TESL du Canada, 20 (2), 38-51.

Noor, K. B. M. (2008). Case study: a strategic research methodology. American Journal of Applied Sciences, 5 (11), 1602-1604.

Oliveira, L. A. (2009). Ensino de língua estrangeira para jovens e adultos na escola pública. In D. C. Lima (Ed.), Ensino e Aprendizagem de Língua Inglesa (pp. 21-30), São Paulo, SP: Parábola Editorial.

Park, G. (2012). "I am never afraid of being recognized as an NNES": One teacher's journey in claiming and embracing her nonnative-speaker. TESOL Quarterly, 46 (1), 127-151.

Park, J. S. (2011). The promise of English: linguistic capital and the neoliberal worker in the South Korean job market. International Journal of Bilingual Education and Bilingualism, 14 (4), 443-455.

Pennycook, A. (2007). The myth of English as an international language. In Makoni, S., \& Pennycook, A. (Eds.). Disinventing and Reconstituting Languages (pp. 90-115), New York, NY: Multilingual Matters.

Pennycook, A. (2001). Critical applied linguistics: A critical introduction. Mahwah, NJ: Lawrence Earlbaum Associates.

Phillipson, R. (2008). The linguistic imperialism of neoliberal empire. Critical Inquiry in Language Studies, $5(1), 1-43$.

Pitman, T. (2013). 'Miraculous exceptions': what can autobiography tell us about why some disadvantaged students succeed in higher education? Higher Education Research \& Development, 32 (1), 30-42.

Rajagopalan, K. (1997). Linguistics and the myth of nativity: comments on the controversy over "new/nonnative Englishes". Journal of Pragmatics, 27, 225-231.

Rivers, D. J. \& Ross, A. S. (2013). Idealized English teachers: The implicit influence of race in Japan. Journal of Language, Identity, and Education, 12, 321-339.

Saad-Filho, A. \& Morais, Lecio. (2018). Brazil: Neoliberalism versus democracy. London: Pluto Press.

Sayer, P. (2015). "More \& earlier": Neoliberalism and primary English education in Mexican public schools. L2 Journal, 7 (3), 40-56.

Selvi, A. F. (2014). Myths and misconceptions about nonnative English speakers in the TESOL (NNEST) Movement. TESOL Journal, 5 (3), 573-611.

Silvestre, V. P. V. (2017). Colaboração e crítica na formação de professores/as de línguas: teorizações construídas em uma experiência com o PIBID. São Paulo: Pontes Editores.

Vandrick, S. (2009). ESL and the colonial legacy: A teacher faces her 'missionary kid' past. In Vandrick, S. Interrogating Privilege: Reflections of a Second Language Educator. (pp. 21-35), Ann Arbor, MI: University of Michigan Press.

Van Lier, L. (1988). The classroom and the language learner. Ethnography and second-language classroom research. London: Longman.

Vološinov, V. N. (1973). Marxism and the Philosophy of Language. Cambridge, MA: Harvard University Press.

Zainal, Z. (2007). Case study as a research method. Jurnal Kemanusiann, 9, 1-6. 
Appendix A

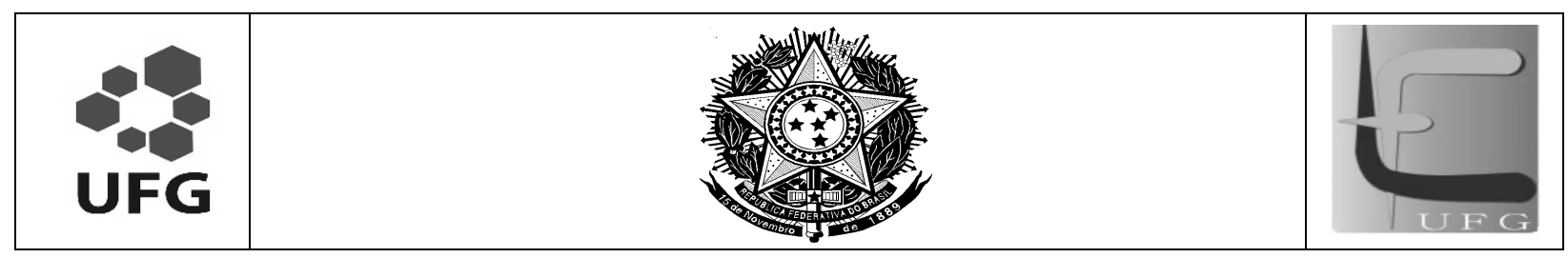

\section{MINISTÉRIO DA EDUCAÇÃO \\ UNIVERSIDADE FEDERAL DE GOIÁS \\ FACULDADE DE LETRAS}

PESQUISA: Língua-sistema versus língua-discurso: diálogos entre pilares da arquitetônica de Bakhtin e a formação linguística-docente de graduandos em Letras-Inglês da UFG

PESQUISADORA: Profa. Carla Janaina Figueredo

\section{Questionnaire}

(To answer the questions below, you don't have to follow normative grammar rules, it is free writing)

\begin{tabular}{l}
\multicolumn{1}{c}{ Undergraduate's name: Age Race Hometown Nationality } \\
$\Rightarrow$ Pseudonym chosen: \\
1. How did you first get in contact with English? \\
\hline
\end{tabular}

\section{How long have you been studying English formally?}

3. In what kind of school (public or private) did you study English to complete your primary and secondary studies? What was the reason for this choice?

\section{Which methodology (ies) did your teacher (s) use to apply in their English classes?}

5. Did you find these methodologies effective to foster your English language learning process? Why or why not?

6. Did you use to interact with your teacher and classmates by means of English? Why or why not?

7. Did you make use of any pedagogical material to learn English? If so, what kind of material (texbooks, Cds, grammar books, etc)? In your opinion, how effective were they to your learning needs?

8. How many hours do you think you used to spend studying English throughout the week? (include here time spent at school and at home)

9. Which learning strategies did you use to improve your English skills in your school days? 
Sink or swim? Responsible situated agency constructed by socioeconomically underprivileged students of English in neoliberal Brazil Carla Janaina Figueredo

10. Have you ever attended English classes at a language center? If so, write down where, when and why.

11. Have you ever been abroad to specifically learn English? If so, where and when did you go? How long did you stay there?

\section{What led you to make a decision for Letras-Inglês at UFG?}

13. Has the will to become a teacher of English always been your first choice before entering the university? Why or why not?

14. Did you have any teaching experience before coming to the university? Did it include teaching English?

15. In your opinion, how good was your English when you started doing Letras? Provide some facts to support your evaluation.

16. What were your first impressions of Letras-Inglês as soon as you started doing it?

17. From the very beginning, were you sure your choice for Letras-Inglês would lead you to achieve your learning and teaching goals? Justify your answer.

18. Would you like to add any other piece of information?

Thank you for taking part in this research.

Professor Carla Janaina Figueredo 


\section{Appendix B}

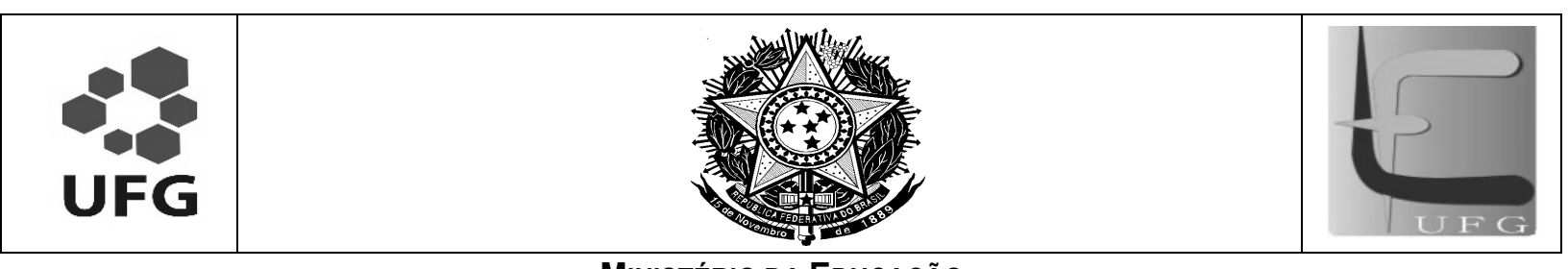

\section{MINISTÉRIO DA EDUCAÇÃO \\ UNIVERSIDADE FEDERAL DE GOIÁS \\ FACULDADE DE LETRAS}

PESQUISA: Língua-sistema versus língua-discurso: diálogos entre pilares da arquitetônica de Bakhtin e a formação linguística-docente de graduandos em Letras-Inglês da UFG

PESQUISADORA: Profa. Carla Janaina Figueredo

Instrumento: diário do participante

This diary has been designed to serve you as an open space for personal reflections concerning your linguistic and teaching experiences undergone throughout your university days at Letras-Inglês. The questions provided here play the role of a guidance, and to answer them, you don't have to follow normative grammar rules, your writing should be as free as possible.

Pseudonym:

\section{The first year in college:}

1. Which changes did you find when you started attending your English classes at the university? Write about how you felt in relation to them.

1.1 At the beginning of your studies, what did the English language represent to you?

1.2 How often did you interact with people (professors, classmates, friends) in English inside and outside the classroom context? Were these interactions relevant to your second language acquisition process? Why or why not?

1.3 Were you encouraged or not by the academic context (English lessons, professors, classmates, academic events, etc) to go on learning English? Provide examples/stories if you wish.

1.4 How did you react and respond to this academic context and to the people you interacted with?

1.5 How was your time with the English language explored?

\section{The second year in college:}

2. What sort of linguistic challenges regarding English did you have to face in your second year of Letras-Inglês? And how did you deal with them?

\subsection{What has changed in your perception of the English language?}

2.2 How did your social interactions evolve in English? Provide examples/stories if you wish. 


\section{Sink or swim? Responsible situated agency constructed by socioeconomically underprivileged students of English in neoliberal Brazil}

Carla Janaina Figueredo

2.3 How did you react and respond to the academic context and to the people you interacted with?

2.4 How was your time with the English language explored?

2.5 Could you get any contributions from the academic context that enhanced your English appropriation process and teaching perspectives?

\section{The third year in college:}

3. Which new things did you employ to your relationship with the English language? What was English like at this point? 3.1 How did you connect with speakers of English (native or non-native) during this time? How did it feel?

3.2 How were social interactions in the classroom context understood by you? How did you feel in relation to them?

3.3 What were your teaching experiences like throughout the third year?

3.4 What has changed in your life right after you started teaching English?

3.5 Which advantages did you take of your time spent in this academic context surrounded by the English language and its teaching?

The fourth year in college:

4. How do you conceive the English language now? What are you able to do with it?

4.1 What sort of person have you become after intensifying your connection with the English language? Is it possible or not to say that at this point you walk hand in hand with it? Why or why not?

4.2 How important were those countless people you interacted with (in college or out of it) for the construction of your identities as a learner and as a teacher of English? How important were you for their lives?

4.3 How do you describe yourself as a teacher of English? What matters the most for you when teaching?

4.4 How could the space or the social universe provided by Letras-Inglês contribute to your second language appropriation and education?

4.5 Do you think your time in college was spent wisely? Was it the right time to learn English and become a teacher? What would you change in your academic trajectory if you could go back in time?

5. How important is your academic-professional formation to the numberless sociocultural/communicative contexts you already take part in or intend to participate in the future?

=> Final question: Which future plans would you like to accomplish from now on? 


\section{(c) EY}

New articles in this journal are licensed under a Creative Commons Attribution 4.0 United States License.

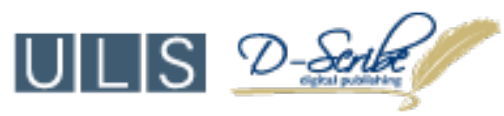

This journal is published by the University Library System, University of Pittsburgh as part of its D-Scribe Digital Publishing Program and is cosponsored by the University of Pittsburgh Press. 